\title{
From Weimar to Winnipeg: German Expressionism and Guy Maddin
}

\author{
Andrew Burke \\ University of Winnipeg (Canada) \\ E-mail: a.burke@uwinnipeg.ca
}

\begin{abstract}
The films of Guy Maddin, from his debut feature Tales from the Gimli Hospital (1988) to his most recent one, The Forbidden Room (2015), draw extensively on the visual vocabulary and narrative conventions of 1920s and 1930s German cinema. These cinematic revisitations, however, are no mere exercise in sentimental cinephilia or empty pastiche. What distinguishes Maddin's compulsive returns to the era of German Expressionism is the desire to both archive and awaken the past. Careful (1992), Maddin's mountain film, reanimates an anachronistic genre in order to craft an elegant allegory about the apprehensions and anxieties of everyday social and political life. My Winnipeg (2006) rescores the city symphony to reveal how personal history and cultural memory combine to structure the experience of the modern metropolis, whether it is Weimar Berlin or wintry Winnipeg. In this paper, I explore the influence of German Expressionism on Maddin's work as well as argue that Maddin's films preserve and perpetuate the energies and idiosyncrasies of Weimar cinema.
\end{abstract}

Keywords: Guy Maddin, Canadian film, German Expressionism, Weimar cinema, cinephilia.

Any effort to catalogue completely the references to, and reanimations of, German Expressionist cinema in the films of Guy Maddin would be a difficult, if not impossible, task. From his earliest work to his most recent, Maddin's films are suffused with images and iconography drawn from the German films of the 1920s. In addition to this reproduction of the visual style and language of the 1920s German studio style, they also pick up on the tropes, themes, temptations and terrors that characterize the cinematic productions of the Weimar period. Instead of offering a complete inventory of what Maddin imports from Weimar to his native Winnipeg, I will investigate and illustrate the ways in which Maddin's numerous feature films and many shorts form part of the rich cultural afterlife of German Expressionism: how it, in modified and mutated ways, continues to 
haunt our screens and fuel our nightmares. I think I can say without controversy that Maddin has played a key role in keeping the cinematic spirit of German Expressionism alive. ${ }^{1}$ And although Maddin is by no means a one-trick pony who has simply hitched his wagon to a Weimar horse, it is nevertheless also fair to say that he has made a number of films where it very much feels that he has found a portal in Winnipeg that somehow takes him through time and space to Alexanderplatz or the Alps.

Unfortunately, and as much as I might want to, I won't be able to touch on all of Maddin's films in this essay. At this point, his catalogue is too deep to attempt any kind of comprehensive, detailed overview of his work within the span of a single article. ${ }^{2}$ But, in some ways, to focus on the films in Maddin's filmography that draw sustenance from the rich visual vocabulary of German Expressionism allows me to light on its Bavarian peaks. In what follows I will zero in specifically on his films that are in direct dialogue with the classics of German Expressionism. But I will also pursue a handful of more oblique connections and unexpected affiliations that concretize the imaginative links between Weimar and Winnipeg that Maddin has forged and fostered over the past thirty years or so, during which time he has become a central figure in Canadian film culture, and has garnered an international reputation for his distinct visual style and wild narrative inventiveness. Maddin himself has never been shy about expressing his love of German film, from the Weimar period to the age of the New German Cinema. In 2012, the Goethe-Institut in Montréal invited Maddin to curate a selection of German films. Not surprisingly, his selection included many from the Weimar period, including Nerves (Robert Reinert, 1919), From Morn Till Midnight (Karlheinz Martin, 1920), The Street (Karl Grune, 1923), Secrets of a Soul (G.W. Pabst, 1926) and Walking from Munich to Berlin (Oskar Fischinger, 1927). Perhaps more important are the introductory notes that Maddin provides, in which he conveys his deep love of German cinema, especially that of the Weimar period. "My parents are Icelandic and Scottish, but somewhere, deep in the darkest red corpuscles of my blood, there must be something German.

1 There is abundant scholarship on the films of the Weimar period and on the innovations of German Expressionist cinema in particular. Sigfried Kracauer's From Caligari to Hitler retains its influential place in any assessment of the period. For more recent overviews of the period and its films, see Thomas Elsaesser's Weimar Cinema and After and Noah Isenberg's edited collection, Weimar Cinema. And for a work that explores the connections between film, the Frankfurt School, and the social, cultural, and political shape of the period, see Miriam Hansen's Cinema and Experience.

2 For a comprehensive and compelling overview of Maddin's career up to 2008's My Winnipeg, see Beard 2010. 
[...] And when I watch the great German films, I get the absurd feeling I could have made them, if only I had lived in another time and been blessed with the blunt trauma genius of the masters featured in this program. The preposterous conviction I could have made these masterpieces is simply the result of an ethos in the films at once so exhilarating and open. When I watch Nerves or Secrets of a Soul I am a young man beholding the art form at its most volatile time, when its vocabulary could have developed in any number of directions, and that I could have taken it in another direction for good had I held a camera in those pioneering days.” (Maddin 2012, n.p.)

Maddin's films actualize, to some degree, this "preposterous conviction," not through any sort of time travel that would actually place him on the ground in Germany in the 1920s, but through his persistence in this desire to reanimate the sense of openness and possibility that distinguishes the films of that time and place. Maddin's films are not hollow pastiches, merely enamoured with the look and feel of a past era, but are experiments in recreating the historical volatility that existed at an earlier moment in film's history, when other futures were possible. And this fascination with the past and the unrealized possibilities it represents is there in Maddin's work from the very beginning.

Perhaps the most striking thing about even the earliest of Maddin's films is how fully formed they are, both stylistically and conceptually. This is perhaps, to some degree at least, a retrospective illusion. From the vantage point of the present, what viewers now see in The Dead Father, Maddin's debut short from 1985 and Tales from the Gimli Hospital, his debut feature from 1988, are those elements that would find expansion and development in his later films. Nevertheless, the stylistic and thematic integrity of Maddin's body of work cannot be chalked up to retrospective illusion alone. The Dead Father establishes a cinematic terrain haunted by paternal loss and characterized by uncanny events and occurrences. The ostensible setting of that first film, the Dominion of Forgetfulness, not only suggests some vaguely defined Mitteleuropa, evocative of the psychic landscape of the Weimar period shaped by the traumas of the early decades of the twentieth century, but also names the territory that later Maddin films would so often occupy. The Dominion of Forgetfulness serves as a kind of shorthand for Maddin's favoured cinematic terrain. It names the amnesiac Winnipeg and myth-deprived Manitoba that his films occupy and enrich.

From the very beginning, Maddin took aim at that most cherished of Canadian cinematic tendencies, the impulse toward documentary and social realism, and turned it on its head. His is a cinema that consists of fabrications and fabulations, 
a cinema that invests in deep melodrama and invents surreal mythologies. Even though, as Maddin has long claimed, the outline for Tales from the Gimli Hospital was cribbed from a community history written by the Sisters of the Rotarians or some other benevolent local organization, it offers no straightforward history of the township or of New Iceland (Vatnsdal 2000, 45-46). Instead, Maddin takes semi-true tales that date from the late nineteenth century, such as a fishing competition overseen by Lord Dufferin or an account of the traditional Viking sport of Glima wrestling, and cinematically embroiders and enlarges them in a way that makes them seem straight from the Sagas. At the same time, of course, they are shot through with a streak of the absurd and, as Maddin has said in numerous interviews, these surreal set pieces derive at least in part from a desire to antagonize his own ancestral community, to satirize, as he acidly observes, "how humorously obsessed with their own history [...] the gallery of sourpusses known as Canadian Icelanders [...] are" (Vatnsdal 2000, 45).

However, if this begins to explain some of the content of these early works, it does not quite account for the look and style of these films, which evoke early cinema and are built out of what was, from the vantage point of the mid-1980s, an archaic and eclipsed cinematic vocabulary. Maddin's grainy, inky historical Gimli might be chalked up to some imagined Nordic affiliation with Carl Theodor Dreyer, yet Maddin himself points to Erich von Stroheim and his 1924 film Greed as his primary visual influence for the film. He does admit, however, that there is no way he could, working with limited budgets and rudimentary technology, reproduce the intensity and clarity of von Stroheim's images, and that it is hard to replicate the grandeur of Greed when working with sets that, as Maddin notes, "were, like, eleven feet wide" (Beard 2010, 406). [Fig. 1.]

Perhaps the best answer to the speed with which Maddin developed his signature style resides in Winnipeg itself. In the years immediately before he made his debut short and feature, Maddin, along with a group of friends, had immersed himself in the cinema of the 10s, 20s, and 30s, drawing on a rich archive at the University of Winnipeg that has long since been liquidated and lost. In a 1991 interview, he says, "since I hadn't seen a colour movie for three years when I made Tales, the language and rhythm of silent black and white features came as a second nature" (Jones 2010, 21). Even beyond this milieu of layabout cinephiles obsessed with silent film, it often seems that Winnipeg is populated by those in the grip of the past. Whether it is the widespread civic resentment toward the Panama Canal, which is commonly understood to have compromised Winnipeg's full development into the Chicago of the north in the 
1910s, or the fond memories of the 1960s when Centennial dollars sparked a civic building boom and suburban expansion that accelerated the city's growth and development, the past looms large in the civic imaginary. ${ }^{3}$

On the cinematic front, it is perhaps telling that the first production of the Winnipeg Film Group, 1976's Rabbit Pie, was a collaboratively-made pastiche of a 1930s slapstick comedy. And perhaps the most influential filmmaker to emerge in the early years of the Film Group was John Paizs, whose Three Worlds of Nick trilogy of short films established the cinematic vocabulary that he would fully develop in his debut feature Crime Wave in 1985. As Geoff Pevere writes, what made Paizs's film such a revelation was its commitment to a grab-bag of unloved genres and ephemeral forms. "Where the official versions of national cultural history tended to cling to documentary, scruffy realism, experimental cinema, highminded McLarenesque animation and literary coming-of-age tales set on oceanic prairies, Paizs's movies glommed onto far more fetchingly mundane influences: horror films and comics, hyper-square industrial films, '50s and '60s sitcom tropes, triple-bill spy movies and cleaning product commercials.” (Pevere 2009, 108.)

With Paizs occupying this vividly-imagined, colour-saturated 1950s and 60s, with its suburban backyard swimming pools and theatres filled with colour crime pictures of the sort that his protagonist so desperately wants to write, it is in every way fortuitous that Maddin was drawn to the films of an earlier period, the era of tinting and two-strip technicolor. ${ }^{4}$ This is not to say that there was some mid-1980s summit of Winnipeg filmmakers to parcel up the past and take responsibility for it decade-by-decade. There were, after all, many Winnipeg Film Group productions grounded firmly in the present, from Elise Swerhone's Havakeen Lunch (1979), an extraordinary work of prairie vérité, to Jon Krocker's 38 Jansky Units (1982), a bold and bizarre new wave experiment. ${ }^{5}$ Nevertheless, this larger context of a city and a culture of filmmaking drawn to the old and the outmoded is key to understanding why Maddin would want to revisit the cinematic language of German Expressionism and to make films that, at least in the eyes of one early reviewer, seem comprised of the "rotting images of past cinema" (Jones 2010, 21).

3 For more on the relationship between civic history and Winnipeg's cinematic production, see my forthcoming article entitled Stand Tall: Winnipeg Cinema and the Civic Imaginary.

4 Jonathan Ball's study (2014) of Crime Wave provides an in-depth analysis of that film's innovations and preoccupations as well as details on Paizs's importance to the development of Winnipeg film in general and on the work of Maddin in particular.

$5 \quad$ For more on the centrality of the Winnipeg Film Group and its importance in the cinematic history of Winnipeg, see my The WFG at 40 (Burke 2015). 
Maddin's debut feature, Tales from the Gimli Hospital, was rejected by the Toronto International Film Festival (TIFF), but went on to become a midnight favourite in New York City. Yet, by the time it had gained this cult and critical traction, Maddin was already immersed in preparations for his second feature, Archangel, which would premiere at TIFF in 1990. As extraordinary and expressionistic as Archangel is, with its almost impossible to summarize tale of Allied soldiers fighting on in the wake of the Great War in northern Russia against both Bolsheviks and Huns, it is really Maddin's next film, 1992's Careful, that is my main focus here.

There are two deeply compelling, yet perhaps completely apocryphal, origin stories for Careful. The first, recounted in William Beard's Into the Past: The Cinema of Guy Maddin (2010), has prairie boy Maddin visiting the Rockies and suddenly remembering a conversation he once had with University of Manitoba film professor Howard Curle. In that conversation, Curle mentioned that in 1920s Germany the mountain picture was as popular a film genre as the western was in the United States. This sudden remembrance sparked a desire in Maddin to make a mountain picture despite, he claims, having never actually seen one (Beard 2010, 88). The second one, gleaned from an interview with Maddin and the producer for several of his early films, Greg Klymkiw, has Klymkiw in the chair at the shop of Winnipeg's legendary octogenarian barber and ardent cinephile Bill Sciak, whom he and Maddin had conscripted to provide the cast and crew of Archangel with historically accurate late 1910s haircuts. When Sciak asked what style he himself wanted, Klymkiw replied "an Emil Jannings cut." Without a pause, Sciak replied, "from the silent mountaineering pictures?" (Rankin 2008). Klymkiw insists that this lightning quick response, overheard by Maddin, planted the seed for Careful. Whatever story is true, the power of Careful resides in the passion that it brings to its infidelity to the past. It is not by any stretch of the imagination an orthodox remaking of a mountain picture. ${ }^{6}$ Yet it manages somehow, through a combination of deep passion and reckless aesthetic speculation, to do justice to the idea of a mountain picture irrespective of the actual history of the genre. It cobbles together bits and pieces of German Romanticism and German Expressionism to create a mountain melodrama, a kind of operetta without singing, inspired by, but not imitative of, the genre as it was.

6 The mountain film plays a key role in Siegfried Kracauer's argument in From Caligari to Hitler where he criticizes them harshly, suggesting that "the surge of pro-Nazi tendencies during the pre-Hitler period could not be better confirmed than by the increase and specific evolution of the mountain films" $(2004,257)$. For a more recent examination of the Bergfilm that examines the limits and blindspots of Kracauer's assessment, see Rentschler 1990. 
Perhaps the best description of Careful comes from Maddin himself, in a selfreview of the film he wrote for the Village Voice on the eve of a retrospective of his films at the Brooklyn Academy of Music in 2001: "Careful is a pro-incest mountain träumerai shot in the two-strip Technicolor used in that holy year of 1929" (Maddin 2003b, 93). Careful is set in Tolzbad, a fictional Swiss Alpine village cheekily named after the film's screenwriter, University of Manitoba film professor George Toles. The citizens of Tolzbad conduct all their conversations in whispers out of fear that anything louder will trigger a fatal avalanche. The fear of snowy death has come to shape the entire life of the town as well as the identities of its inhabitants, all of whom have internalized the injunction that serves as the title of the film. The film's extraordinary opening sequence offers a whole array of optical tricks and striking shots drawn directly from the image-world of German Expressionism. Just as importantly, the opening speech that accompanies this prologue evokes the form of the fairy tale and establishes the continuity between the Brothers Grimm, German Romanticism, and German Expressionism that forms the very heart of the film. Herr Trotta, a town elder, delivers this speech and lays out the perilous predicament of Tolzbad in terms that are at once fantastic and foreboding: “Careful, Otto. Don’t spill it. Hold your horses! Children! Heed the warnings of your parents. Peril awaits the incautious wayfarer and strews grief where laughter once played. Think twice. I'm sure you can live without that. Don't get wet. Nature has built for us a beautiful world. Allow yourself to drink in its wonder safely. Paths must be climbed with the sure-footedness of a mountain goat, but beware your skill at climbing. The skill assures nothing. A heedless heart can be lured to dangerous heights and a sudden ice film or a single wobbly stone can pry you loose from the path and serenade you with the whistling wind of the death plummet. Then there is always the avalanche - when the snow relaxes its grip on the slope and is dragged downwards under its own crushing weight. The slightest sound or any false move by anyone can trigger these deadly landslides and sweep all into oblivion. Guard yourself and your neighbour against making that fatal sound. Be vigilant. Do you have your binoculars? Use them. Silence. Propriety."

This represents only the initial phase of the prologue, but it delivers the necessary exposition about Tolzbad and its collective fears. It also manages to convey everything the viewer needs to know about the village's deep-seated repression in strikingly visual ways, from the excessive, almost parodic, Germanness of the typeface used for the title card and epigraph to the vertiginous angles and evocative dissolves that structure and shape the montage. The sepia-toned 
tinting throughout the sequence immediately brings to mind the use of colour in Weimar-era cinema to express tone and atmosphere, and Maddin uses shadow plays to illustrate the narrator's repeated injunction to be careful. The language of expressionist theatre is there in Herr Trotta's direct address to the audience and Maddin echoes the vocabulary of classical painting in elaborate tableau shots that picture the frightened populace. Maddin also draws on the wide array of optical tricks developed in German Expressionist film. He applies Vaseline to the camera lens to produce tilt-shift or vignette effects, employs the Schüfften process to evoke landscape panoramas using small-scale models, and uses multiple exposure to communicate the fractured psychic life of the village and its inhabitants. ${ }^{7}$ Maddin has said that in order to do visual justice to the care and caution that informs every aspect of life in Tolzbad, he needed to create a "fragile Repress-O-Vision" that would convey this through the colour, grain, texture, and tone of the image (Vatnsdal 2000, 78). The list above does not even cover Maddin's full repertoire of visual tricks and techniques; missing are his beloved iris effects and superimpositions. Careful is a film that raids the visual toolbox of 1920s German cinema, both Expressionist and beyond, to evoke a generalized sense of cinematic pastness and to communicate an ardent cinephilia fuelled by a deeply melancholic attachment to forgotten forms and exhausted genres.

As Will Straw argues, reviews of Maddin's films commonly struggle to assemble "scattershot inventories of [their] stylistic and historical reference points" (2016, 62), and the critical responses to Careful were no different. In Sight and Sound, Claire Monk suggested the film presents "a kitsch-hell of giant flugelhorns, flaxenhaired maidens and flower-bedecked funiculars" (qtd. by Straw 2016, 62). In Film Comment, Robert Horton suggests the film has "the look of an overstuffed UFA film from the twenties, the tone of an SCTV version of a Wagner opera, and the overall aesthetics of Dr. Seuss" (qtd. by Straw 2016, 62). As Straw notes, these strained critical efforts to itemize the influences on Maddin's film obscure the extent to which the force of Careful resides not in the accuracy with which it recreates its antecedents or the idiosyncrasy of its references, but in the passion and intensity Maddin brings to the process. "Lists such as these are often effective in suggesting the variety of resonances which Careful sets in play. They do injustice, however, to the discipline and consistency with which Maddin patiently unearths and

$7 \quad$ Mike D'Angelo provides a detailed shot-by-shot analysis of the first couple of minutes of Careful's prologue in his Scenic Routes column for the A.V. Club (2014). As D'Angelo argues, the opening section of the prologue does not even get around to the delivering of any kind of critical narrative information: "it's Maddin's way of establishing Careful's idiosyncratic tone and look, giving viewers a bit of time to acclimate themselves before hitting them with genuinely crucial details." 
reinhabits the lost languages of minor, transitional moments in film history. These lost languages are, most of the time, historically authentic, but the peculiar paradox of Maddin's film (and of Careful, in particular) is that the stylistic predecessors of which they so successfully remind us may, in fact, be ones we have never experienced to any significant degree. Reviewers who applaud Maddin's insight into the Bavarian mountain film are unlikely to have seen a great number of these, but that is the point. Maddin's films are both inventive revisitings of genuine past styles and imagined versions of such styles, seemingly drawn (in Careful's case) from such ephemera as the illustrations of children's fairy-tale books or early sound-era operetta. The coherence of Careful's world is not solely an effect of Maddin's careful reconstruction of already existing generic traditions; it springs, as well, from the convincing completeness with which he has imagined such worlds.” $(2017,62$.) For me, the power of Careful resides in the act of imaginative will that it took to create a mountain film amidst the prairie flatness of Manitoba and the sheer topographical uneventfulness of Winnipeg. There has long been the critical temptation to read the restraint and repression of Tolzbad as a thinlyveiled national allegory that captures Canada's fearfulness and timidity. While this reading is both satisfying and seductive, it by no means exhausts interpretive possibilities. ${ }^{8}$ Careful can also be understood on a smaller allegorical scale, as a work concerned with the dynamics of a smaller community or village, which Winnipeg, despite its size, sometimes feels like. [Fig. 2.]

To understand Careful as civic allegory is, in a way, to understand it in relation to The Cabinet of Doctor Caligari. After all, Caligari is a film that similarly starts with civic celebrations and a village fair but soon gives way to a vision of a town torn apart by hidden and illicit desires, complicated and conflicted love triangles, mysterious visitors, and sinister and supernatural machinations. This is not to suggest that in its day-to-day experience Winnipeg is as plagued by Caligari-esque interlopers as this comparison to Caligari's Holstenwall and Tolzbad implies. Yet, as fantastical and fairy-tale-ish the film is, Careful's preoccupation with shame and desire form the basis of Maddin's more directly autobiographical civic investigations in My Winnipeg (2008). ${ }^{9}$ Of course, the ongoing force of Siegfried Kracauer's work, despite whatever critiques, suggests the nation cannot be jettisoned absolutely, that just as Caligari offers an uncanny premonition of the fascist tyranny that

8 Initial Canadian reviews of Careful often flirted with the possibility the film is best read as national allegory, but the most comprehensive argument that it can be understood as such is Wolfram R. Keller and Christian Uffmann's Careful...Canadians: Guy Maddin's Allegory of Canadian Identity.

$9 \quad$ For a detailed reading of My Winnipeg, see Wershler. 
would follow, so too, buried somewhere in Careful is a diagnosis of national traits and tendencies. Yet, I can't help but think that there's something more provincial, municipal, civic at play in Careful, a fascination with the dynamics of the village, town, or city as both an actual and imagined community, rather than necessarily being an allegorical representation of a national body.

Before I move forward in Maddin's filmography, I want to propose another way in which Careful draws on the legacy of German Expressionism, not by referencing it directly but by being in dialogue with other contemporary enthusiasts for the period. My favorite section of Careful is the whole, meticulous account of Grigorss and Johann's training at Tolzbad's Butler School, as overseen by Frau Teacher, magnificently played by Jackie Burroughs. The clear inspiration for this sequence is Robert Walser's 1909 novel Jakob von Gunten. The novel tells the tale of the eponymous Jakob who enrols in a training school for servants and upsets the delicate balance of the school when he comes between the brother and sister who run it. Even though Walser's novel resists any simple categorization, as Expressionist or otherwise, it seems to take place in precisely the kind of claustrophobic dream-world captured in The Cabinet of Doctor Caligari. It is a novel that invites an expressionist vision, which is precisely what happened when it was adapted for the screen by The Brothers Quay as Instituta Benjamenta, or This Dream Called Human Life, which I would claim was a huge influence on Careful if it were not for the inconvenient historical fact that it was actually made three years after Maddin's film. Nevertheless, and perhaps a little counterintuitively, I think there is still a way that Maddin's Careful is influenced by a film that had not yet been made. It is this: The Brothers Quay had once before beat Maddin to the punch in adapting a cult literary work when they released their animated version of Bruno Schulz's The Street of Crocodiles in 1986. When Maddin introduced this film as part of the Pacific Film Archive's Cinema Mon Amour series in 2016, he explained how he felt when he first learned of the adaptation and about The Brothers Quay: "I first heard of them in one of those horrifying moments. My favorite author for decades now has been Bruno Schulz, the author of the short stories The Street of Crocodiles (1934). Bruno Schulz is practically the reason I wanted to make films. I didn't make my first film until I was 29 years old; it was a short movie. I was hoping that at the end of 10-15 years of filmmaking to be good enough to be able to make a Bruno Schulz adaptation [...]. So I had this vague plan to get better and better until somehow I could make a film that would be like what Bruno Schulz did on the page. The next thing I know, my screenwriter/collaborator George Toles called me to say, 'Have you 
heard that The Street of Crocodiles is now a movie?' He was all excited but I was like, 'No! My entire future is gone!' It was advertised to play on PBS that night so I watched it quickly, full of hatred, dying to hate the movie and to hate whoever made it. But it ended up being one of those things where the film was just so great that my feelings went beyond jealousy."

So even though Institute Benjamenta came after Careful, there is, weirdly, a way in which Maddin's admiration for The Brothers Quay and The Street of Crocodiles may have played some part in shaping his depiction of the repressed, regulated, and routinized world of the Butler School in Careful even before they delivered their official version a few years later. Perhaps just as importantly, this affiliation with the Brothers Quay also counteracts the mythology of Maddin as a cinematic lone wolf wholly disconnected from the rest of the film world. ${ }^{10}$

I want to jump forward now to the series of films that Maddin made in the 2000s, which may not initially seem as explicitly indebted to expressionist cinema as either Archangel or Careful, but which draw on the German 1920s in different and somewhat more unexpected ways. Cowards Bend the Knee (2003) started life as an installation at Toronto's Power Plant gallery. In its initial form, it consisted of ten standalone peepshow devices, which at once recalled cinema's origins in Edison's cinematograph and invited visitors to think about the proximity of the scopophilic and the pornographic. For the film version, these separate short films were strung together sequentially in ten chapters that tell the story of Guy Maddin (played by Darcy Fehr), a hockey player for the Winnipeg Maroons who, after convincing his lover Veronika to have an abortion, unceremoniously dumps her when seduced by the vixenish Meta. Little does he know that Meta wants nothing more from him than to murder her mother, hairdresser-slash-bordello madam, who, whilst having an affair with Guy's teammate Shaky, had conspired to murder Meta's beloved father. Perversely, Meta has saved her father's hands in a formaldehyde-filled jar and coaxes Guy into agreeing to have maniacal back-alley sawbones Dr. Fusi amputate his hands and replace them with those of her dead dad. Dr. Fusi, however, finds some ounce of decency in himself and cannot complete the procedure, so he tints Guy's own hands with blue Barbicide to replicate the stains from the preservation fluid and fakes stitching around the wrists. However, Guy, unaware of Dr. Fusi's

10 As well as being in dialogue with the history of cinema, Maddin's films fit alongside contemporary experimental cinema similarly engaged with the materiality of the moving image and the persistence of past forms, from Bill Morrison, whose Light is Calling (2004) Maddin also selected to screen as part of the Cinema Mon Amour series, to Peter Tscherkassky, whose Outer Space (2000) and Dream Work (2002) Maddin celebrates in a Village Voice piece on a screening series held at the Anthology Film Archives. 
deception, is horrified by what he thinks are his new hands. Even though they have given him great goal-scoring powers, they fill him with dread and make his relationship with Meta feel awkwardly incestuous. Admittedly, this synopsis only really brings us up to Chapter 4, but hopefully conveys something of the film's narrative excesses and surreal enthusiasms.

It is strange to think of this story as having its basis in autobiography, but the general shape of Maddin's life is there, even if he sets it back in time a little. The film is set in Winnipeg in the 1930s and the action unfolds in a hairdressing salon and at the fabled Winnipeg arena. As is confirmed in Maddin's My Winnipeg, released four years later in 2007, his mother and aunt owned and operated a salon on Winnipeg's Ellice Avenue when Guy was a child and his father was the manager for the Winnipeg Maroons, who played at the Winnipeg Arena. What is especially compelling about Cowards is how it exemplifies the relationship between personal memory and cinema memory in Maddin's cycle of autobiographical films. In Cowards Bend the Knee, Brand Upon the Brain (2006), and My Winnipeg, the so-called Me Trilogy, the border between family history and cinema's past is unstable and they frequently shape and form one another. Maddin uses his own personal history as yet another vehicle for his ongoing exploration of the lost languages of cinema and its forgotten genres. I also have the sense that it is only through cinema, through these older genres defined by excess and artificiality, that Maddin can find a way to understand the truth of his childhood and to recreate the intensely felt experience of it.

So, while Robert Wiene's The Hands of Orlac (1924) may seem an odd choice of film through which to understand a cluster of childhood traumas and desires that have shaped him as a person, it works remarkably well in the case of Cowards Bend the Knee. Wiene's film, made in Austria less than five years after the completion of The Cabinet of Dr. Caligari, retains much of the earlier film's Expressionist tone and tendencies. This is at least in part due to the presence of Conrad Veidt, who brings as great an intensity to Orlac as he did to Cesare in the earlier film. Orlac is a concert pianist who loses his hands in a railway accident. Knowing that her husband's hands are his livelihood, his wife begs the surgeon to save them. Moved by her desperation, the doctor transplants the hands of the recently-executed murderer Vasseur onto Orlac.

Even though he does not tell Orlac of this deception, the pianist is horrified by his new hands from the very moment he awakes. He looks at them in horror and is haunted by what he thinks is the ghost of their true owner. When he eventually learns that he now has the hands of a murderer, he fears that he has also inherited 
the capacity, even the desire, to kill. When Orlac's father is discovered murdered, the fingerprints on the knife lead directly back to his son, who fears that he committed patricide in some kind of hand-driven frenzy. He then becomes the victim of blackmail when a man claiming to be Vasseur emerges, claiming that he was saved from execution by an unscrupulous assistant of the surgeon who, after the execution, sewed his head onto a living body and gave him prosthetic hands. This man, however, turns out to be a fraud. The police reveal that he tried to frame Orlac for the murder of his own father by using a pair of rubber gloves imprinted with Vasseur's fingerprints. With this revelation, Orlac is exonerated and his acceptance of his new hands is confirmed when he finally brings himself to embrace his wife.

The first thing to notice is that the complexity of the plot of Cowards matches that of Orlac twist for turn. And, yes, even though there are a whole slew of contemporary puzzle films that very much fetishize narrative complexity, almost as an end in itself, it serves an altogether different purpose in Expressionist cinema and Maddin's revisions of it. ${ }^{11}$ The convolutedness of the plot does not seem solely at the service of the spectator's narrative pleasure in either Caligari or Cowards, but is a sign of these films' frantic desire to express some deeper truth about human life, despite the full recognition that there are psychic dangers in doing so. In interviews, Maddin frequently makes the point that melodrama should not be thought of simply as "life exaggerated" but as "life uninhibited" and this can serve as a model for understanding the revisioning of Orlac into Cowards Bend the Knee: it is not that you, as a spectator, have to wipe away all the excess - the narrative excess, the visual excess, the emotional excess, the musical excess, the actorly excess - in order to find the truth that lies underneath. What lies beneath is merely the events and occurrences of life, the real truth of which can only be approached via the excess that initially seems to obscure or obliterate it. This is possibly the main element that Maddin takes from German Expressionism, this idea that the articulation of some kind of lived, emotional or psychological truth is expressible only through a grandness or excess, which always runs the risk of being written off as kitsch, camp, or pastiche. [Fig. 3.]

Hands play an important part in the obstacle that contemporary audiences sometimes feel stands between them and taking seriously older forms, especially the classics of the silent period. At the beginning of the printed screenplay of Cowards Bend the Knee, Maddin includes "A Note on Hands" that presumably forms part of the instructions he gave his actors before they embarked on the

11 For an overview of the contemporary Hollywood puzzle film, see Buckland 2014. 
project. He writes: "in this melodrama each actor will be required to use his or her hands expressionistically. Frequently, the actors' hands, rather than their faces, will be used to convey required emotions and plot turns" (2003a, 18). It is hardly surprising that Cowards, as a silent film that draws heavily on The Hands of Orlac, would require a fair bit of robust hand acting. What is important here is the way that Maddin's film frames an older form of acting and allows the spectator to see what has been lost in the transition to newer styles of acting. Drawing on the work of Keir Keightley, Will Straw suggests that we might see Maddin's film as a kind of "historical essay on style" $(2016,66)$. This would mean understanding it as an archaeological work that encourages an audience to confront what has been lost in the transition from an expressionist or excessively melodramatic mode to the dominant and far more restrained realisms of the present.

Cowards is also a good example of how the reach of Expressionism is redoubled as a consequence of its overwhelming influence on film noir. Maddin describes Cowards as a "hockey and hairdressing noir" and has suggested that only noir cinematography could reproduce the high contrast lighting and the inkiest of inky blacks that defines mid-century hockey photography. Likewise, the smoky and sexualized interior of the salon-bordello evokes the illicit spaces of film noir. It scarcely needs to be said that the basic visual vocabulary of film noir was shaped by German exiles who came to Hollywood over the course of the 1930s and in the early 1940s. Directors such as Billy Wilder (Double Indemnity, 1944) and Fritz Lang (Scarlet Street, 1944) were key to the development of noir, as were cinematographers such as Rudolph Maté (Gilda, 1946). Hollywood is, of course, important enough to the story of the export and influence of German Expressionism that Westwood inevitably intervenes between Weimar and Winnipeg. Recognition of this not only acknowledges the centrality of Hollywood in consolidating and promoting the Expressionist style in the years that followed the collapse of the German film industry when the Nazis came to power, but also signals Maddin's own love for all kinds of offbeat Hollywood studio productions of the 1930s, 40s and 50s. ${ }^{12}$

Maddin's engagement with expressionist-inflected film noir continues in $M y$ Winnipeg. For the film, Maddin cast legendary noir actress Ann Savage to play

12 Gerd Gemünden provides a comprehensive overview of German directors, screenwriters, cinematographers, and technicians in exile in Hollywood and elsewhere during the Nazi period and after in his Continental Strangers: German Exile Cinema, 1933-1951 (2014). For a sense of Maddin's infectious enthusiasm for all manner of minor and major Hollywood productions of the 1930s and 40s especially, see his occasional column, Guy Maddin's Jolly Corner, which appeared sporadically in Film Comment during the 2000s. 
his mother. She appears in those scenes where Maddin attempts to forensically reconstruct moments from his childhood in the effort to understand why the city has such a tenacious hold on him. Savage is best known for her work in Edgar G. Ulmer's Detour from 1945, a low budget or "Poverty Row" noir produced outside the studio system. Detour is a cult classic that has acquired a legendary reputation because it is one of the most grimly fatalistic films in the whole noir cycle. That reputation is down in large part to Savage. Her femme fatale Vera is equal parts venom and spite. Throughout the film, she heaps abuse on Tom Neal's sad-sack protagonist. She reminds him time and again that he is nothing more than a "sucker" and a "sap." It's perhaps typical of Maddin to think, "I must get this woman to play my mother!" but I'm more interested in the way that Savage connects the film, via Westwood, back to Weimar.

The conduit for this history, the man who connects it all, is Ulmer, whose career spans both decades and continents, binding together a series of different cinematic movements and film styles. ${ }^{13}$ Ulmer started out as an assistant director working with F.W. Murnau on The Last Laugh in 1924 and followed Murnau to Hollywood, where he worked as the art director on the Academy Award winning Sunrise in 1927. He returned to Germany and co-wrote and co-directed People on Sunday in 1930 alongside Curt Siodmak, Robert Siodmak, Billy Wilder and Fred Zinnemann, all of whom, of course, went on to write and direct classic Hollywood films. They were part of a cinematic community in exile, alongside Ulmer, who translated the images and ideas of Expressionism into the American idiom. Ulmer stayed in Germany long enough to be a set designer on Fritz Lang's $M$ in 1931, but he returned to Hollywood when the Nazis came to power, and directed the Universal horror classic The Black Cat in 1934. After that, throughout the 1930s and 40s, he directed dozens of low-budget pictures, from Bronxset Yiddish comedies to military documentaries about tuberculosis. Finally, Ulmer even directed two Ukrainian-language films for former Winnipegger and legendary Ukrainian-Canadian showman and producer Vasile Avramenko, who firmly believed these films would be the start of a Ukrainian Hollywood. Even though both Natalka Poltavka (1936) and Cossacks in Exile (1938) were shot in New Jersey, they found their largest audience in the Ukrainian diasporic communities of Western Canada. ${ }^{14}$ Cossacks in Exile was restored and digitized by the Provincial Archives of Alberta in 2016, based on a print that circulated

13 Noah Isenberg's Edgar G. Ulmer: A Filmmaker at the Margins (2014) provides a comprehensive overview of Ulmer's life and films.

14 For more on the extraordinary life and career of Vasile Avramenko, with fine detail on how Ulmer came to direct the two films, see Martynowych 2014. 
as part of an itinerant picture show that travelled to Ukrainian communities in Saskatchewan from the 1930s to the 1950s. Cossacks in Exile is not a particularly Expressionist film. Nevertheless, via Savage and her connection to Ulmer, Maddin incorporates into My Winnipeg something of the Expressionist twenties that a figure like Ulmer embodies and exemplifies, and which he took into exile and transformed into a series of incredibly esoteric films that are tied to Maddin's Winnipeg in unexpected yet extraordinary ways.

I want to conclude by taking a brief look at Maddin's latest film, 2015's The Forbidden Room, which he co-directed with Evan Johnson. The Forbidden Room is a film comprised of lost films. Maddin and Johnson made up a list of hundreds of lost films, mostly from the early days of cinema, and set about recreating them on a frantic schedule of one a day, working in public at Centre Phi in Montreal and the Centre Pompidou in Paris. This initial phase of the project was titled Hauntings, and sought to restore to existence those lost objects of cinephile fantasy. In certain cases, as with Mikio Naruse's lost film from 1931, The Strength of a Moustache, Maddin and his collaborators had little more to work with than the title itself. But, as should already be clear, this kind of speculative reimagining is exactly Maddin's forte. Hauntings and The Forbidden Room also have an online component, titled Séances, which can be accessed via a dedicated NFB site. For each visitor to the site Séances generates a unique film algorithmically made up of the hours and hours of surplus footage Maddin shot during Hauntings. The film, complete with title and usually fitting in some broad mix of genres and styles, disappears immediately after the film ends. It is perhaps a bit odd to think that Maddin, a filmmaker whose aesthetic is so grounded in his love for cinema's pasts, has become a filmmaker whose practice looks so boldly forward to its digital future. Yet, it is the flexibility that the digital offers that has allowed him to dive even deeper into cinema's past and to explore its lost, deteriorating, forgotten, or orphaned works. ${ }^{15}$

For enthusiasts of German Expressionism, Maddin's take on F.W. Murnau's lost Der Janus-kopf from 1920 might very well be the highlight of The Forbidden Room. Der Janus-kopf was Murnau's adaptation of Robert Louis Stevenson's The Strange Case of Dr. Jekyll and Mr Hyde. The script was written by Hans Janowitz, who was one of the writers of The Cabinet of Dr. Caligari and it featured Conrad Veidt as both Jekyll and Hyde. Given this cast and crew, the film surely would be, had it survived, a key part of the German Expressionist canon; its disappearance

15 The full story of how Hauntings, The Forbidden Room, and Séances came together is even more complicated than my brief synopsis suggests. For more on the origin, the development, and realization of these projects, see Straw 2016. 
is one of those incalculable losses that cinephiles and film scholars mournfully lament. As such, there is some consolation in seeing Maddin's remake. It is one of the few sections of The Forbidden Room in black and white and it masterfully works within the Expressionist idiom, both visually and thematically. It features all the shadows you would expect and concludes with the protagonist being whacked on the head with the eponymous Janus head by his doppelgänger.

Since it is perhaps a bit too straightforward an homage, I want to conclude by briefly looking at another one of The Forbidden Room's sequences: the one featuring the great Udo Kier as a man so debilitatingly obsessed with buttocks that he seeks out a surgeon to remove sections of his ass-addled brain bit by bit to try to cure him of his affliction. What I like about this admittedly bonkers sequence is the way that it recalls and revisits the debilitating obsessions, the uncontrollable impulses that thread through Weimar cinema and in many ways define it. This history of men distraught and destroyed by desire begins, of course, with The Cabinet of Dr. Caligari itself and Werner Krauss's asylum director submitting to the repeated injunction "du Musst Caligari Werden!" "You must become Caligari!" There is also, of course, Orlac, who believes that his hands are in control of him rather than his head or his heart. And then there is poor Werner Krauss again in Pabst's Secrets of the Soul (1926) playing a man who, after a minor accident in which he cuts his wife whilst shaving the nape of her neck, is distraught over the idea that he does really want to kill her. Additionally, there is also Emil Jannings in Joseph von Sternberg's The Blue Angel (1930), so smitten with Marlene Dietrich's Lola Lola that he goes from respected teacher to destroyed man. Finally, there is Peter Lorre in Fritz Lang's $M$ (1931), the child murderer driven to kill by a homicidal impulse that even he does not seem to fully understand.

In The Forbidden Room, this vision of a man seized by compulsion is Weimar cinema's legacy and Udo Kier's inheritance. And, while in The Blue Angel Von Sternberg soundtracks Emil Jannings's fall with Marlene Dietrich singing the sublime Falling in Love Again, in The Forbidden Room, Kier's desperate decline unfolds to the mockingly melancholic sound of The Final Derriere by Los Angeles duo Sparks. I hope that it is not too minor or incidental point with which to conclude, but I think that this gap between the pathos of the Dietrich song and the bathos of the Sparks track perfectly sums up the relationship that Maddin has with cinema's past. Far from treating it as sacrosanct or producing po-faced homages to it, Maddin embraces the reckless mad passion that is at the very heart of it. Perhaps the greatest connection between Winnipeg and Weimar, between Guy Maddin and German Expressionism, is the willingness to use cinema's 
most expansive repertoire of tricks and artifices, to venture into the realm of the uninhibited and the irrational, in order to produce something both deeply authentic and thoroughly artificial.

\section{References}

Ball, Jonathan. 2014. John Paizs's Crime Wave. Toronto: University of Toronto Press.

Beard, William. 2010. Into the Past: The Cinema of Guy Maddin. Toronto: University of Toronto Press.

Buckland, Warren, ed. 2014. The Hollywood Puzzle Film. London and New York: Routledge.

Burke, Andrew. 2015. The WFG at 40. In Reflecting Light: 40 Years of Canadian Cinema, ed. Cecilia Araneda, 18-20. Winnipeg: Winnipeg Film Group.

Burke, Andrew. 2019. Stand Tall: Winnipeg Cinema and the Civic Imaginary. In Oxford Handbook of Canadian Cinema, eds. Janine Marchessault and Will Straw, 269-284. Oxford: Oxford University Press.

D'Angelo, Mike. 2014. The prologue of Careful epitomizes Guy Maddin's oneof-a-kind genius. A.V. Club. https://film.avclub.com/the-prologue-of-carefulepitomizes-guy-maddin-s-one-of-1798268434. Last accessed 04. 27. 2017.

Elsaesser, Thomas. 2000. Weimar Cinema and After: Germany's Historical Imaginary. London: Routledge.

Gemünden, Gerd. 2014. Continental Strangers: German Exile Cinema, 19331951. New York: Columbia University Press.

Hansen, Miriam. 2011. Cinema and Experience: Siegfried Kracauer, Walter Benjamin, and Theodor W. Adorno. Berkeley: University of California Press.

Isenberg, Noah. 2014. Edgar J. Ulmer: A Filmmaker on the Margins. Berkeley: University of California Press.

Isenberg, Noah, ed. 2009. Weimar Cinema: An Essential Guide to Classic Films of the Era. New York: Columbia University Press.

Jones, Alan. 2010. Far from the Maddin Crowd: Guy Maddin Interviewed. In Guy Maddin Interviews, ed. D.K. Holm, 19-27. Jackson: University of Mississippi Press.

Keller, Wolfram R. and Christian Uffmann. 2008. Careful...Canadians: Guy Maddin's Allegory of Canadian Identity. In Screening Canadians: CrossCultural Perspectives on Canadian Film, ed. Wolfram R. Keller and Gene Walz, 161-182. Marburg: Universitätsbibliothek Marburg. 
Kracauer, Siegfried. 2004. From Caligari to Hitler: A Psychological History of German Film. Princeton: Princeton University Press.

Maddin, Guy. 2002. You Give Me Fever. Village Voice. https://www.villagevoice. com/2002/06/11/you-give-me-fever/. Last accessed 27. 04. 2017.

Maddin, Guy. 2003a. Cowards Bend the Knee. Toronto: Power Plant.

Maddin, Guy. 2003b. From the Atelier Tovar: Selected Writings of Guy Maddin. Toronto: Coach House Press.

Maddin, Guy. 2012. Carte blanche à Guy Maddin: 19 janvier au 16 mars 2012 [Carte blanche to Guy Maddin: January 19 to March 16, 2012]. Montreal: Goethe Institut.

Martynowych, Orest T. 2014. The Showman and the Ukrainian Cause: Folk Dance, Film, and the Life of Vasile Avramenko. Winnipeg: University of Manitoba Press.

Pevere, Geoff. 2009. Dream On: The Crimes of John Paizs. In Place: 13 essays 13 film-makers 1 city, ed. Cecilia Araneda, 106-113. Winnipeg: Winnipeg Film Group.

Rankin, Matthew. 2008. Gooseflesh and Hard-ons: Guy Maddin \& Greg Klymkiw discuss the making of Archangel with M. Rankin. In Archangel: A Film by Guy Maddin. Winnipeg: Winnipeg Film Group.

Rentschler, Eric. 1990. Mountains and Modernity: Relocating the Bergfilm. New German Critique no. 51: 137-161.

Straw, Will. 2009. Reinhabiting Lost Languages: Guy Maddin's Careful. In Playing with Memories: Essays on Guy Maddin, ed. David Church, 58-69. Winnipeg: University of Manitoba Press.

Straw, William. 2016. Interview with Guy Maddin. La Furia Umana no. 28. $\mathrm{http://www.lafuriaumana.it/index.php/61-archive/lfu-28/566-william-straw-}$ interview-with-guy-maddin. Last accessed 27. 04. 2017.

Vatnsdal, Caelum. 2000. Kino Delirium: The Films of Guy Maddin. Winnipeg: Arbeiter Ring.

Wershler, Darren. 2010. Guy Maddin's My Winnipeg. Toronto: University of Toronto Press. 


\section{List of Figures}

Figure 1. Maddin's historical Gimli in Tales from the Gimli Hospital (1988). (Copyright Guy Maddin, courtesy Winnipeg Film Group.)

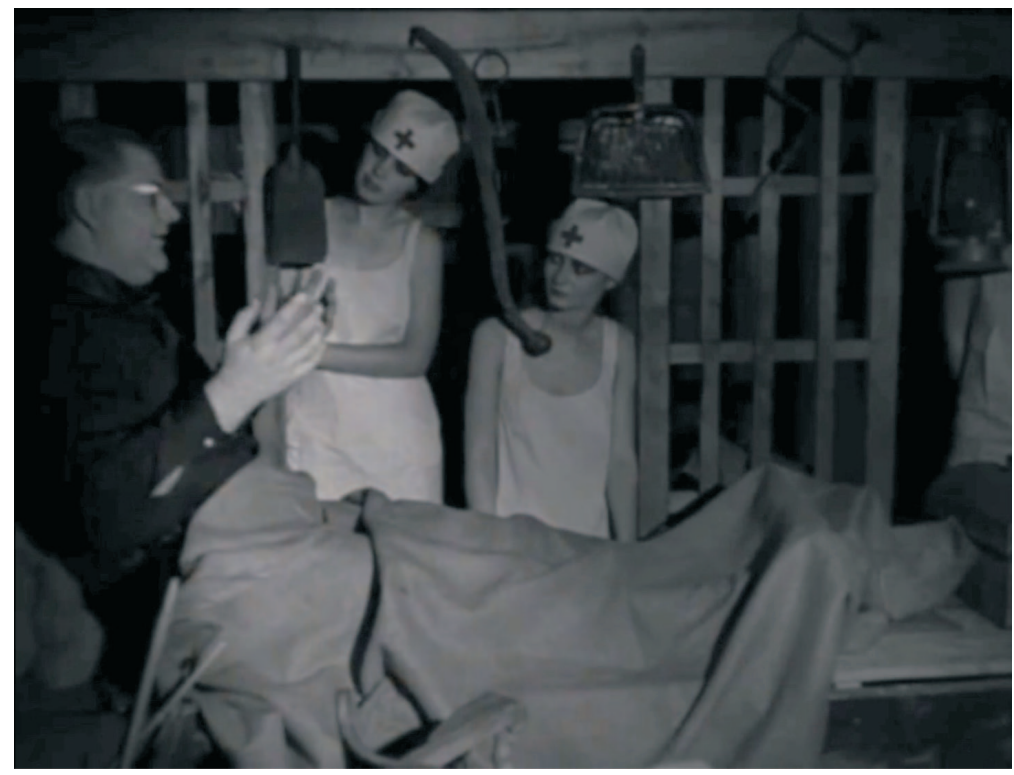

Figure 2. The citizens of Tolzbad assemble in Guy Maddin's mountain film Careful (1992). (Copyright Guy Maddin, courtesy Winnipeg Film Group.)

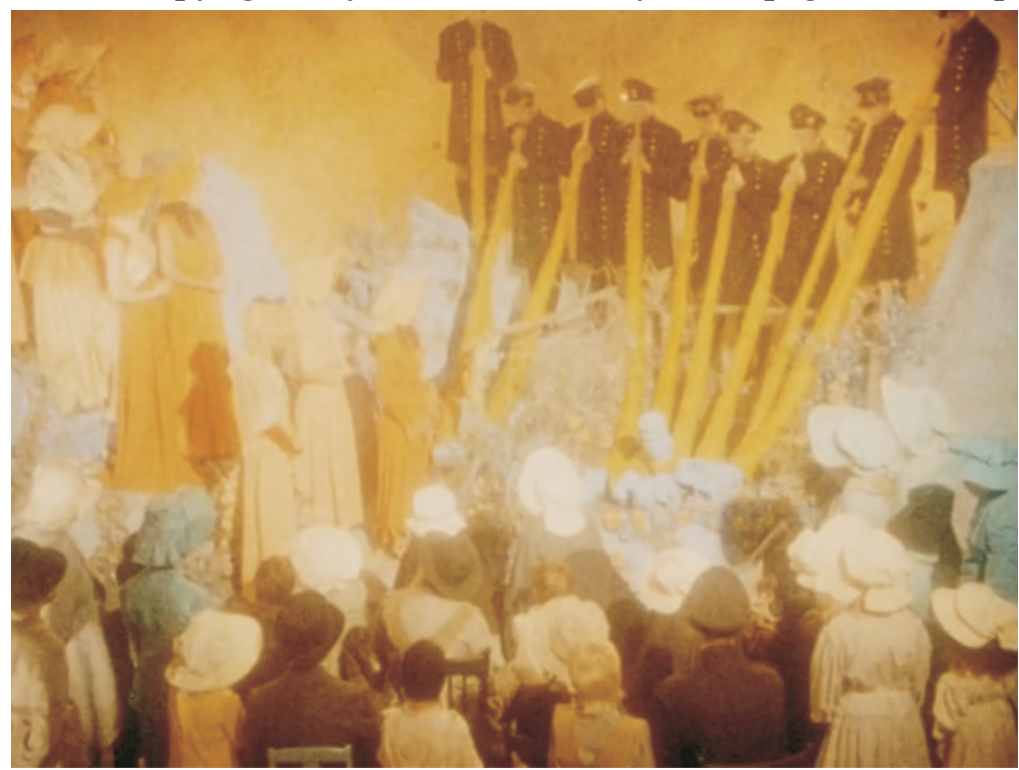


Figure 3. Guy Maddin's Cowards Bend the Knee (2003) draws extensively on Robert Wiene's The Hands of Orlac (1924). (Copyright Guy Maddin, courtesy Winnipeg Film Group.)

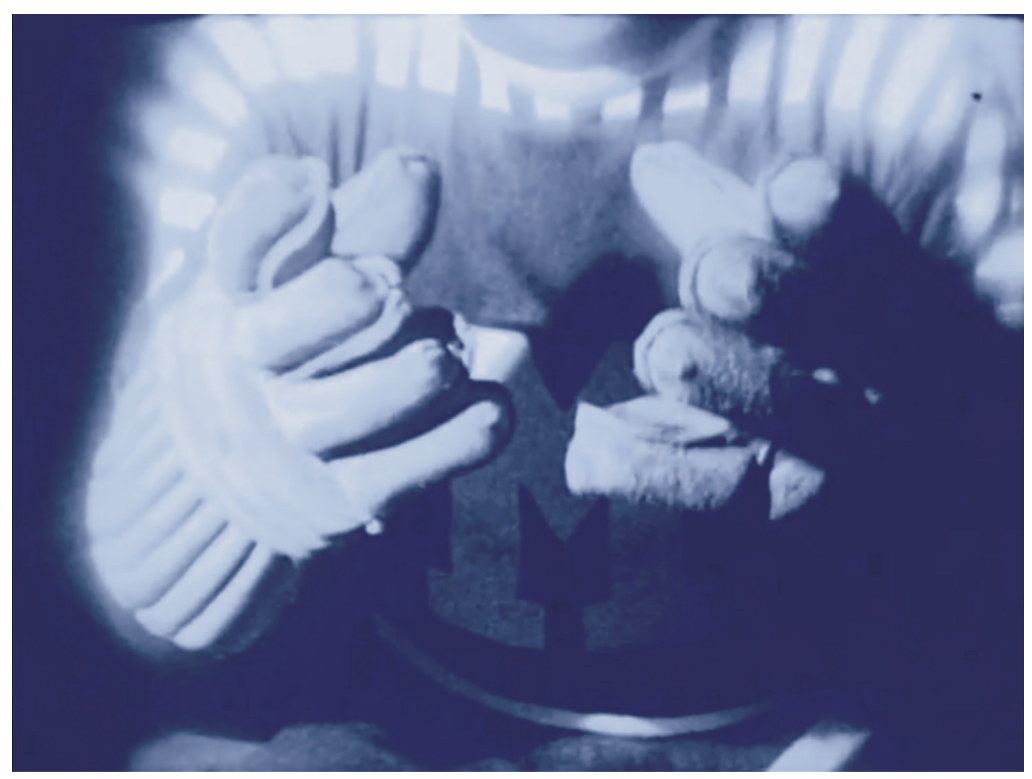

